\title{
Application of the Ontology of Activity in the Automation of Decision-Making Processes in Crisis Management of Organizations
}

\author{
By A Nikiforov \& S Smyk
}

Abstract- Crisis management, or, in other words, management in the "strong" maneuver mode, refers to the most complex types of organizational management. The large dimensionality of decision-making tasks coupled with a shortage of time put forward an urgent need to automate crisis management procedures. However, such features of crisis management as: weak structuring of the tasks to be solved due to their uniqueness, uncertainty of conditions, volatility of goals (aspects) of management - serve as an obstacle to automation. The ontological approach offers a number of advantages with solutions and problems of crisis management automation. Applying the activity ontology to organizational multi-aspect management, one expands significantly the application field of formalized methods. It makes alternatives more detailed.

Keywords: crisis management, organizational management, aspect of control, decisionmakingspace, procedural regulations, the ontology of activity, tensor of network transformation, design of procedural regulations, decision-making process.

GJSFR-A Classification: FOR Code: 170202

Strictly as per the compliance and regulations of:

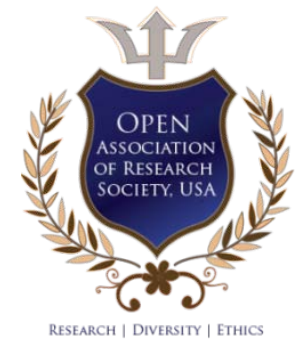

(C) 2021. A Nikiforov \& S Smyk. This is a research/review paper, distributed under the terms of the Creative Commons AttributionNoncommercial 3.0 Unported License http://creativecommons.org/licenses/by-nc/3.0/), permitting all non commercial use, distribution, and reproduction in any medium, provided the original work is properly cited. 


\title{
Application of the Ontology of Activity in the Automation of Decision-Making Processes in Crisis Management of Organizations
}

\author{
A Nikiforov $^{\alpha} \& S_{\text {Smyk }}{ }^{\sigma}$
}

\begin{abstract}
Crisis management, or, in other words, management in the "strong" maneuver mode, refers to the most complex types of organizational management. The large dimensionality of decision-making tasks coupled with a shortage of time put forward an urgent need to automate crisis management procedures. However, such features of crisis management as: weak structuring of the tasks to be solved due to their uniqueness, uncertainty of conditions, volatility of goals (aspects) of management - serve as an obstacle to automation. The ontological approach offers a number of advantages with solutions and problems of crisis management automation. Applying the activity ontology to organizational multi-aspect management, one expands significantly the application field of formalized methods. It makes alternatives more detailed. The activity factors of performers and multiple aspects of management can be taken into account. In the article, we discuss a novel approach to decision-making process in organizational management. The process of forming decision-making alternatives is interpreted as a threefold grouping of the activity ontology elements at discrete moments time. A method of distributed formation of the ontological networkdescribedwhich puts its elements in groups using expert methods while ordering its alternatives by particular criteria.Such method usually implemented in practical design of corporate automated control systems. As a result, we formulated the tasks for scientific research concerned with development of scientific and methodological apparatus of crisis management. These are: the formation of decision-making spaces (sets of alternatives) that are invariant to aspects of management; specification of characteristics for these invariants (alternatives) based on ontology elements; and reconfiguration of the whole order of operations depending on required aspect of management. Approaches to solving the formulated tasks are shown.
\end{abstract}

Keywords: crisis management, organizational management, aspect of control, decision-makingspace, procedural regulations, the ontology of activity, tensor of network transformation, design of procedural regulations, decision-making process.

\section{INTRODUCTION}

n management of organizations (corporations, military forces), decision-making process is the most important element, upon which the final efficiency of the organization's functioning rests. The tasks solved by the leader (commander) in the act of making a decision

Author a o: Kharkov National University Air Force, Ukraine. e-mail: aleksey.nikiforov.62@gmail.com are extremely complex. Particularly difficult for practical implementation are the problems of organizational management, especially when "strong" maneuversare carried out, or put in other words, when crisis management is involved.

Only few managers out of many possess the necessary skill sets to carry out this kind of management. Such specialists are usually singled out and put in separate category called "crisis managers". The main challenges of crisis management are:

- Weak structuring of the task being solved, which is solved for the first time every time, every task being unique;

- $\quad$ Large dimensionality of the problem;

- Weak studid (at the beginning of the decisionmaking process) intra-system relationships, which must be taken into account when predicting the consequences of decisions made.

The ultimate goal of the process of developing a solution of managing an organization for carrying out any maneuver is: forming a list of tasks for departments; determination of the time and order of fulfillment of the assigned tasks; distribution of available resources by tasks (departments); establishment of the order of functioning of divisions in solving the tasks assigned to them. In terms of the degree of detail, the developed solution covers two lower hierarchical levels of the considered control system. That is, the decision is being worked out right down to the workshop (subdivision) , a separate production, a separate workshop (combat crew, crew). In this case, as a rule, the factor of personification is taken into account ( personal interests (preferences) and the capabilities (competence) of performers).

An additional difficulty of organizational management is caused by the fact that the above decision parameters, as a rule, are determined on the basis of a one-time (one-step) management procedure by the decision-maker (DM). Such techniques, for example, as a step-by-step approximation to the desired result by solving a sequence (cascade) of extreme problems, in most cases are not applicable. All constituents of a solution are highly interdependent. It is impossible to vary any particular part of the system by freezing its environment. The decision is made at once 
on all aspects, in the entirety of the presentation of management processes.

Thus, organizational management, carried out in the mode of "strong" maneuver (crisis management), has a number of problems associated with the impossibility of theoretical elaboration of decisionmaking tasks in advance and their multidimensionality. One possible method of solving these problems protrusion is automated crisis management processes. This determines the relevance of the scientific task of implementing a formalized representation of such management processes.

The first significant attempts to conduct coordinated management of large organizations (the economy of the state) on a scientific basis were undertaken more than 100 years ago. These attempts include the GOELRO plan (1920) [1] and inter-sectoral balance model by V.V. Leontiev [2]. The plan provided for the implementation of a "strong" maneuver for the development of the entire country on the basis of building inter-sectoral balances "production consumption". The bottlenecks of this approach were:

- The impossibility of providing the necessary degree of detail of the formed management. Inter-branch balances did not allow to go down to the level of individual enterprises;

- $\quad$ The impossibility of forming management taking into account the activity of the behavior of economic subjects (market relations).

The third bottleneck, unobvious at the time, was the lack of adaptability of models and methods to multiaspect management in conditions of initial uncertainty.

In the future, the development of models and methods of organizational management, including in crisis management modes, took place in these three areas: detailing, taking into account the factor of activity (subjectivity) of performers and adaptation.

The improvement of mathematical models in order to increase their detailing and expand the area of formalized description is associated with L.V. Kantorovich [3]. He proposed a universal method for optimal management of industry (enterprise) - the method of linear programming. This made it possible to expand the scope of the formalized description of processes of organizational management, covering the local level (the level of enterprises). In essence, the results obtained by Kantorovich represented a mathematical apparatus for optimal resource management at the local level. However, the proposed approach was efficient under the conditions of repetitive typical cycles of operation. Crisis management regimes involving the introduction of external input into the model of its structure, had been remained an unsolved problem. In [4] - [6], decision-making models based on mathematical programming methods were further developed. The main problem here was the formation of optimality criteria that would correctly reflect the management goals. S. Optner suggested using the methods of systems analysis for this purpose. Development problems (management goals) were formalized in the form a difference of vector defined in the decision-making space [7]. Taking into account [7], a system of planning, programming, budgeting (PPB) (program-target management) of the defense sector was developed [8], [9]. Here, hed been a sufficient degree of detailing of the decisions made in terms of the allocation of limited resources has been achieved. However, the question of the formation of the decisionmaking space, the evolutionary change of this space, subject to the continuity of the decision-making procedures used, remained open.

The direction of improving methods and models of decision-making, which is associated with taking into account the active behavior of performers, is presented in the works of N.D. Kondratyev.In [10] and [11] he formulated the main provisions for an indicative method of managing a multi-structure economy (multi-agent system). Kondratyev's approaches were developed by $\mathrm{K}$. Landauer in [12] and formed the basis for systems of market economy management [13]. The results obtained in these works were, to a greater extent, the character of a set of some rules, empirical proportions. They lacked systems of mathematical models suitable for a formalized description of management procedures. Theoretical studies that set out a formalized description were presented in the works of: V.N. Burkov [14] on the theory of active systems; Yu B. Germeier and [15] on the theory of hierarchical games; J. Nash [16] , J. von Neumann and O. Morgenstern [17] on the study of equilibrium states of coalition-free interaction of economic entities. The theory of active systems has become a practical application of game theory. Here, models mechanisms of organizational management were proposed that could be practically implemented and which made it possible to describe decision-making procedures as hierarchical problems of allocating limited resources with distributed formation of initial data [18]. With the proximity of the models of the theory of active systems to the actually existing processes of organizational management, nevertheless, it should be noted the insufficient level of their adaptability in the conditions of multi-aspect management.The same disadvantage is inherent in the information theory of hierarchical systems [19], [20]. Here, the activity of performers and the hierarchical nature of control systems are taken into account by means of a system of hierarchically subordinate optimization problems, which are repeatedly solved in the process of iterative procedure of forming a general solution [21]. In order to achieve the flexibility of models that take into account the active behavior of performers, the theory of multiagent systems has been applied since the late 80s of the last century [22]. Multi-agent models combine 
graph theory and optimal control theory and allow simulating complex interactions of subjects with a relatively simple formalized representation of their behavioral reactions [23]. The bottleneck of this method is the degree of adequacy of the representation of the behavioral reactions of the subjects (management bodies). To overcome this difficulty, the complex behavior of subjects in multi - agent systems is described in the form of an activity ontology (a network of needs and opportunities) [24], [25]. The main difficulty in the dissemination of the ontological approach is: the need for significant restructuring and networks of needs and opportunities coupled with adding their own target attitudes on the part of subordinate decision-making centers.

The third direction - is adaptability in conditions of multiple aspects and uncertainty of management. This direction is presented in the works, in which are presented: methods of forming a full space decisionmaking; procedures for constructing a system of metrics that are invariant to aspects of management; processes for the development of procedures for the synthesis of structures (networks) with established properties. V.A. Bazarov-Rudnevs works from 1924 to 1928 were devoted to methods of forming decision-making space [24]. Later, when developing the concepts of situational and strategic management, the scientific results of Bazarov-Rudnev found their development in the methods of designing the space of hypothetical future states (worlds) when developing strategic goals for the development of the US military forces [27], [28]. The disadvantage of this method was the arbitrariness in determining the initial set of parameters of the decisionmaking space. In [29], a procedure (categorical analysis) was proposed that allows one to introduce some formalism into this element. By combining elements of categorical pairs, the relative completeness of the analysis of the decision-making space was ensured. Also in [29], an approach is proposed for the formation of a system of metrics for complex management objects. These metrics is derivatives of power, and are invariant to changes of management aspects. Unfortunately, the proposed approaches have not yet found wide practical application. G. Kron [30] proposed a method for synthesizing networks (structures) with given properties using transformation tensors formed according to certain criteria. Crohn and his followers noted the great potential of tensor transformations in the design of organizational management systems. In [31], a method was proposed for the synthesis of structures based on the use of theoretical-system constructs [32] and the apparatus of steps of the multitude [33]. In fact, a mechanism was proposed for the automated (automatic) transformation of procedural regulations for the work of organizations in the context of changes in aspects management. In [34], the application of the apparatus of of steps of the multitude in the design of ACS is considered In [35], the application of both the apparatus of steps of the multitude and libraries of constructs in the design of an automated control system for the security of subjects in the military-political and socio-economic spheres is considered. Theoretical developments [35] formed the basis for the preliminary design of the automated control system for the national defense of the Russian Federation, which was adopted for service 2013.Methods for the conceptual design of organizational management systems have not yet become widespread in the theory and practice of organizational management due to the relatively high degree of novelty of approaches.

This article is devoted to solving the problem of detailing the decisions made and adapting organizational management systems. Here, an approach is considered for a formalized description of the decision-making process for the crisis management of an organization based on the ontology of its activities. The use of an ontological network gives advantages both in solving problems of detailed representation of the decisions made, and in adapting them to changes in the target and parametric space of multi-aspect control.

The content of the ontology of the organization's activity and the method of its formation are considered.

Scientific tasks for the development of mathematical models and methods for solving the problem of automation of crisis multi-aspect management of organizations are formulated.

\section{The Content of the Decisions made AND THE ONTOlogy of Activity}

One of the features of organizational management, which determines the structure and content of decisions that are made, is the property of hierarchy [18]

As a rule, when considering management processes, three hierarchical levels are distinguished: the level of the corporation and the development goals of the corporation; the level of the subjects of the corporation (enterprises) and the tasks that are solved in certain areas of corporate activity; the level of specific performers (departments) and tasks, of algorithms for solving these tasks, of resources that are used in individual subjects of the corporation. Such a three-link structure of the control system corresponds to the provisions of the theory of viable systems by S. Bir [36], as well as the hierarchy of criteria for assessing the quality of a chess game, which was proposed by M.M. Botvinnik [37].The figure clearly shows the target hierarchy according to Botvinnik (fig. 1) in the form of: 1 - lower link (action of individual chess pieces), 2 middle link (action of groups (combinations) of pieces) and 3 - higher link (chess position as a whole).

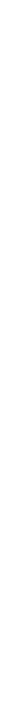




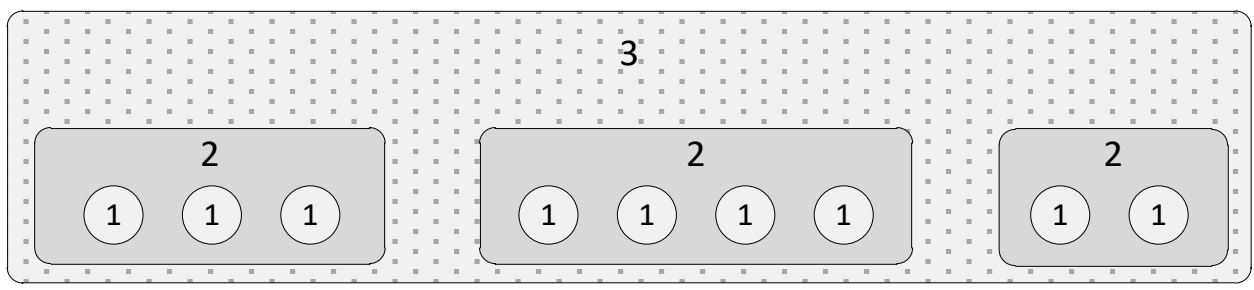

Figure 1: Interrelation of objective functions in three-link control according to M.M. Botvinnik

Decisions, which are taken in the three-link control system, have a hierarchical structure, similar to the scheme shown in fig. 1. The structure of the formed decision is represented as a hierarchically nested network diagram [38] (fig. 2).

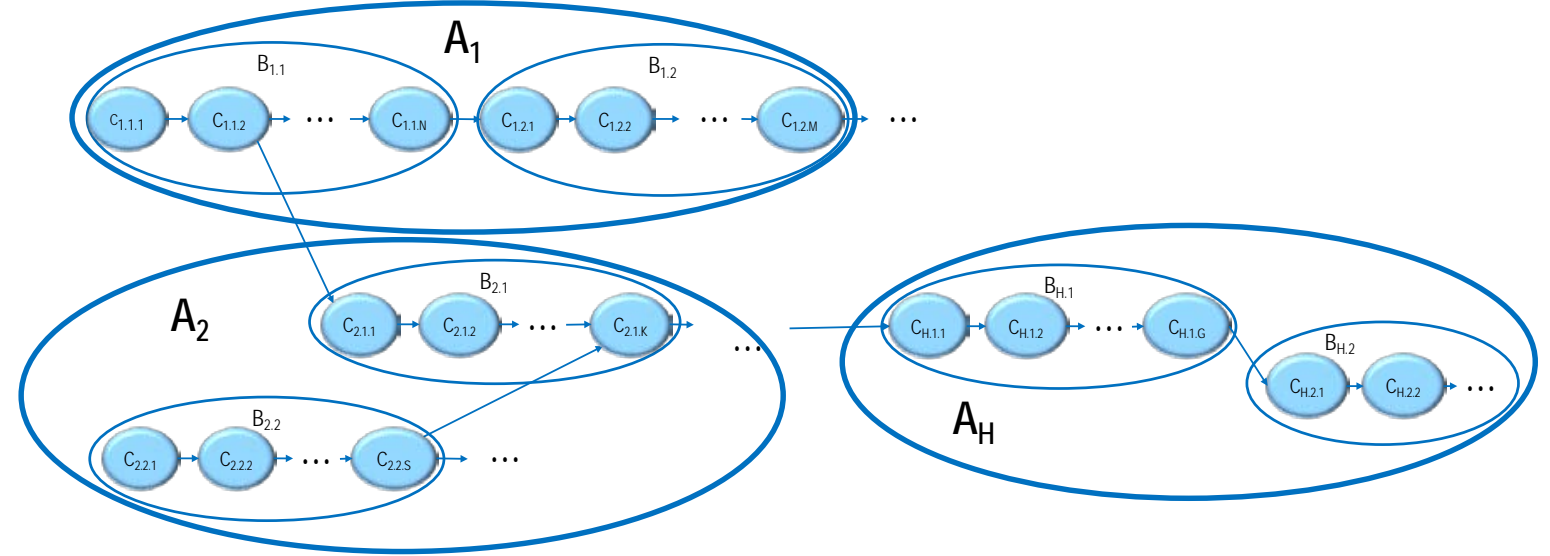

Figure 2: Solution structure

The upper (third) hierarchical level is represented by actions, $A_{i}, i=1, \ldots, H$, which reveal the concept of an organizational maneuver (operation). In general, the concept represents a certain structure, which unfolds in time.The middle (second) level is represented by actions that detail the concept, $B_{i, j}$, $i=1, \ldots, H, j=1, \ldots, N_{i}$. These are the tasks of individual subjects of the corporation, enterprises, and unit. The lower (first) level is the actions of individual performers, individual technical complexes, stages of performing individual tasks of the second level, $C_{i j, k}, i=1, \ldots, H$, $j=1, \ldots, N_{i}, k=1, \ldots, M_{i, j}$. Here $H, N_{i}, M_{i, j}, i=1, \ldots, H$, $j=1, \ldots, N_{i}$ - the number of actions that make up the concept, the $i$-th action of the second level and the ij -th action of the first level, respectively.

The edges of the network diagram (fig. 2) establish the order of execution in time of the actions that are planned. The sequence of actions is established on the basis of links between the actions of the lower (first) level.

The generated action plan, which is presented in the form of a network diagram (fig. 2), can be written as a double boolean of the set of binary relations of the actions of the concept $A_{i}, i=1, \ldots, H$ and of discrete moments of time $t_{\tau}, \tau=1, \ldots, T$

$$
P=\mathcal{P}(\mathcal{P}(A \times A) \times t),
$$

where $\mathrm{P}-$ is the generated solution (plan).
In turn, each action of the concept is a double boolean of binary relations of actions of the second level and discrete moments of time

$$
A=\mathcal{P}(\mathcal{P}(B \times B) \times t) .
$$

For actions of the second level, by analogy with (1) and (2), we can write

$$
B=\mathcal{P}(\mathcal{P}(C \times C) \times t) .
$$

Taking into account (1) - (3), the formed solution can be written as:

$$
P=\mathcal{P} \mathcal{P} \mathcal{P}(\mathcal{P}(C \times C) \times t) .
$$

Boolean of binary relations of actions of the first level (stages or elements of performing tasks of the subjects of the corporation, actions of individual performers and technical complexes), $\mathcal{P}(\mathrm{C} \times \mathrm{C})$, is the ontology of the organization's activities.

Thus, the decision-making process looks like a threefold grouping of ontology elements and discrete moments of time. That is, speaking about the formalized representation of the processes of crisis management of organizations, it is necessary to single out the tasks: development of procedures for grouping elements of ontology, as well as - synthesis, in fact, of the ontological network.

The procedures for grouping the elements of ontology cannot be considered separately from the 
methods of their synthesis. At the moment, only expert methods for the synthesis of alternative solutions have been implemented, where separate procedures for the quantitative assessment of characteristics are used. Nevertheless, starting from empirical methods of decision-making, it is possible to approach the construction of mathematical models of crisis management.

\section{ini. Distributed Method of Forming the Ontology of the Organization's Activities when Preparing a Solution}

Ontology activity of the organization is presented as a course e set of discrete alternatives. Alternatives are formed for a given decision-making space and are evaluated using indicators (criteria) defined in this space. The difficulty in forming such an ontology is the dependence of the content and structure of its elements on the decision-making space. That is, the ontology of activity should be created for a specific managerial case.

To solve the problem of forming an activity ontology that would take into account the peculiarities of specific situations of crisis management, one should use the procedures for transforming the initial (degenerate or invariant to the decision-making space) ontology for a specific space (specific aspect) of management.

Despite the undoubted attractiveness of this approach, unfortunately, its practical implementation still remains an unsolved problem that requires additional theoretical research. At this stage, when designing automated organizational management systems, the method of early formation of ontologies for the established classification of managerial situations is used, as well as methods of accelerating the processes of filling a variety of alternatives through the use of automation tools.

So, for example, in [38] a method is described for the distributed formation of alternative options for the functioning of an organization for given goals and conditions of use. Due to the implementation of a distributed process of work of experts (of performers preparing proposals (initial data) for the decision to be made), an acceptable speed of preparation and satisfactory detailing of decisions were ensured. To ensure consistency in the work is, performers, preparing options for proposals th at a decision, has been used mechanism of dispatching automated procedures variable of data preparation. The essence of the dispatcher's work when controlling the process of variable solution of informational -computational tasks is illustrated in fig. 3.

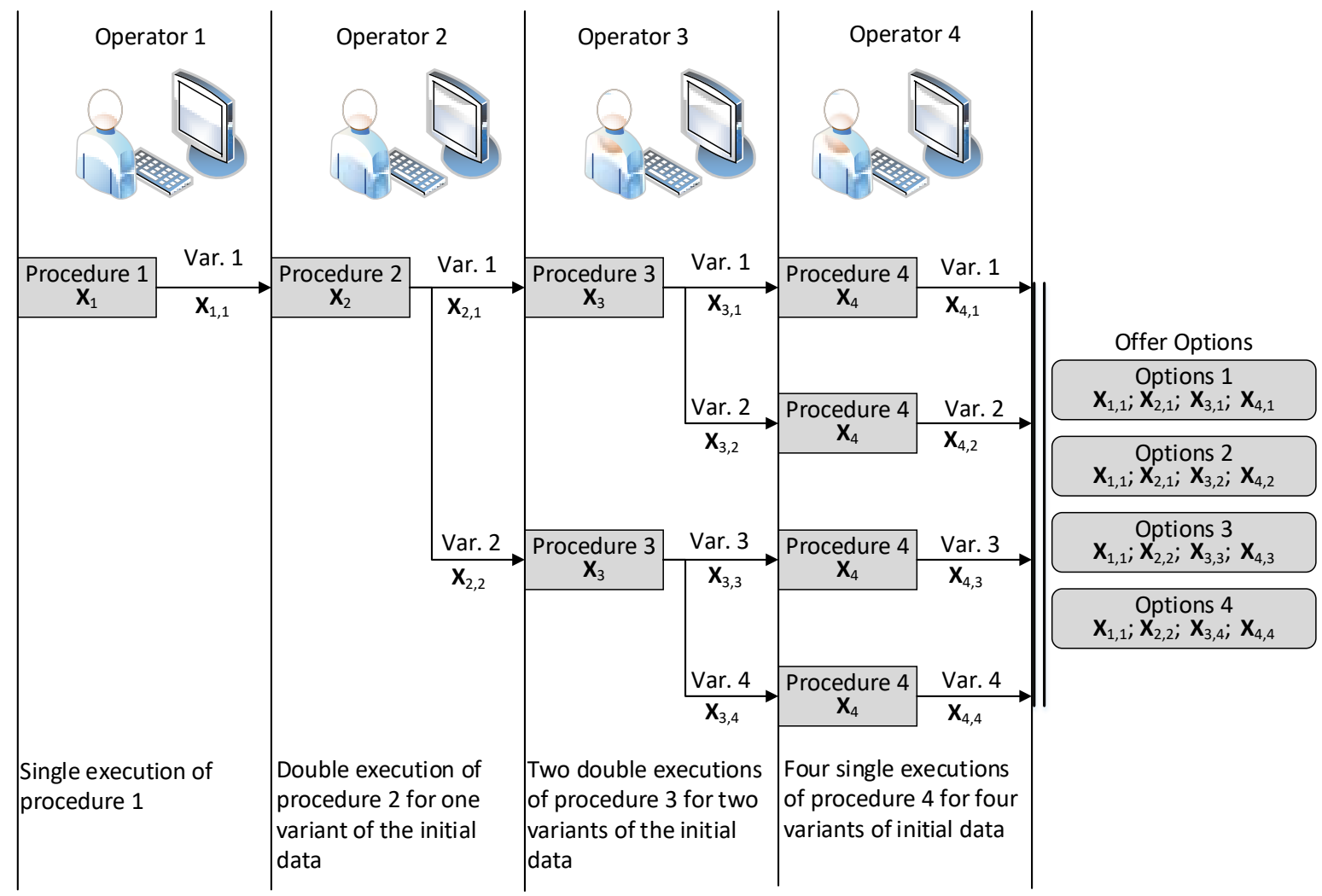

Figure 3: The essence of the dispatcher's work in the distributed solution of information - computational tasks for the preparation of options for proposals in the solution 
The dispatcher's task was to form sets of initial data for information- calculation procedures, solved in an established logical sequence, in order to determine the parameters of the order of using the subdivisions and means organizational. Each of the tasks under consideration formed its own set (its own vector) of functioning (state) parameters.

The prepared versions of proposals were ordered in a certain way for subsequent decisionmaking by the senior boss. Ordering alternatives was carried out on the basis of partial criteria defined on parametric space of the decision-making (fig. 4).

Each alternative comprises all best (for the set conditions) the order of application entities of the means of the subdivisions, $U$, and where in the implemented parameters state, $X$. The quality of the proposed alternative was assessed by the level of efficiency on the private aspect of management, $W(X, U)$. The specified conditions were: resource provision and established norms (prescriptions) on use the subdivisions of organization.

Generating the structure of alternative options was did according to the levels of resource provision $R_{s}^{\mathrm{gvn}}, s=1,2, \ldots, S$, where $\mathrm{S}$ - is the number of introduced levels of resource provision, and the levels of utility (compliance) of the established norms (rules) with the goals and objectives being solved, $Q_{j}(X, U)=0, j=$ $1,2, \ldots, J$, where $Q_{j}(X, U)$ is some function (most often implicitly specified) of the equivalent replacement of the undertaken actions to ensure the $j$-th level of utility; $J$ the number of levels of utility of the established norms. The generated structure of alternatives was set on a grid with dimensions $S \times J$. For each $s, j$-th node of this network performers offerid such a procedure for application of the means, $U_{f}\left(R_{s}^{\mathrm{gvn}}, Q_{j}\right), f=1,2, \ldots$, $(S \times J)$, and realized such state parameters, $X_{f}\left(U_{f}\right)$, $f=1,2, \ldots,(S \times J)$, which maximizes levels their effectiveness, $W_{f}$.

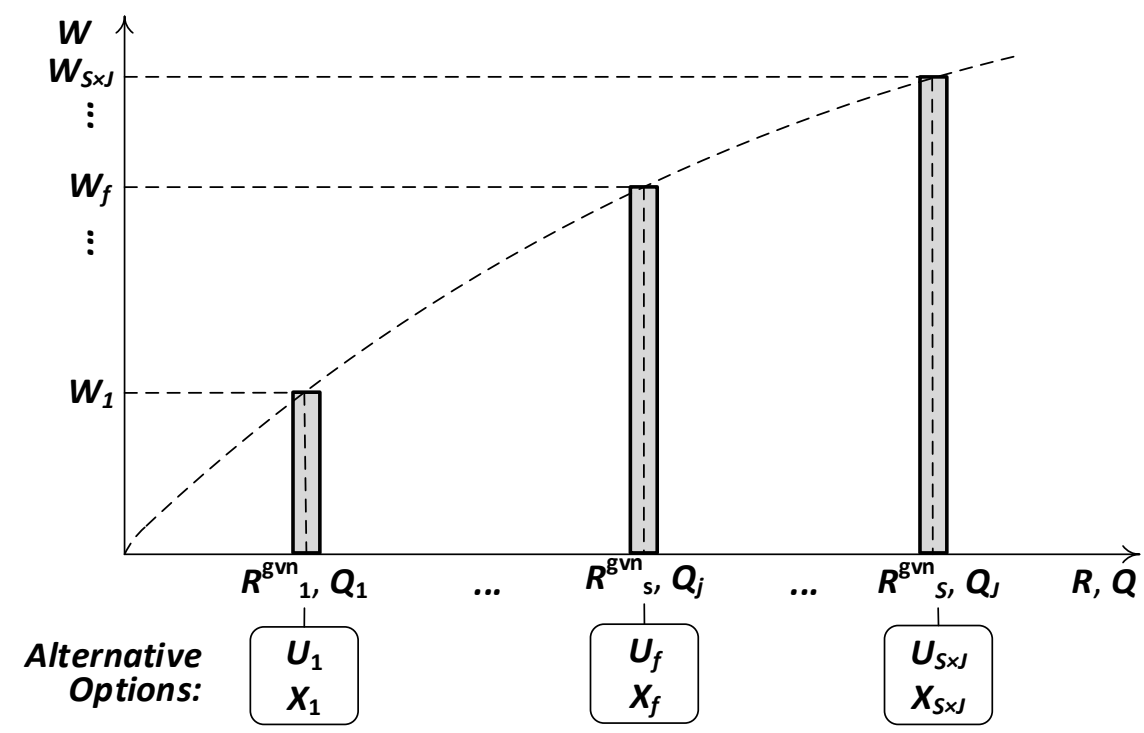

Figure 4: Arrangement of alternatives by partialcriteria

The formed set of alternatives in dimension $S \times J$ was used to support the decision-making of the senior chief in a dynamic environment, with situational management. The ordered presentation of alternatives made it possible not to carry out a complete enumeration of the formed set of alternative options when solving the problems of synthesis (adjustment) of the plan for use the subdivisions and resources of organization.

In the general case, the procedure for combining variants of the lower hierarchical level into an alternative for the senior management level was presented as a procedure for the allocation of limited resources. After the formation of the list of alternative options for performing the previously set tasks, a search was made for such a combination of alternatives for the functioning of subordinate units, which should ensure the maximum result (maximum quality) of the functioning of the system of the senior hierarchical level while maintaining resource constraints and norms (rules) of functioning.

The advantage of the described method of forming alternate embodiments of functioning (activities ontology) organization is the fact that the content of the formed alternatives does not contradict the local criteria of utility (success), which are used by junior managers, and meets their current capabilities.

Described mechanism control should reled to methods of decision-making process with the counter way of collecting initial data [14] (fig. 5). The figure shows that at the first stage, the senior boss sets preliminary tasks, formulates in enlarged form what he 
would like to receive from lower-level entities as suggestions when implementing the planned maneuver of the organization. At the second stage, the executors prepare alternative proposals in the decision of the senior boss. At the third stage, a decision is made: the consolidation (selection) of the method of functioning and the level of resource provision for subjects of the subordinate level on the basis of the presented set of alternative proposals. This decision-making mechanism is widely represented in the practice of organizational management.It is for this reason that he was taken into service in the design of the ACS described in [38].
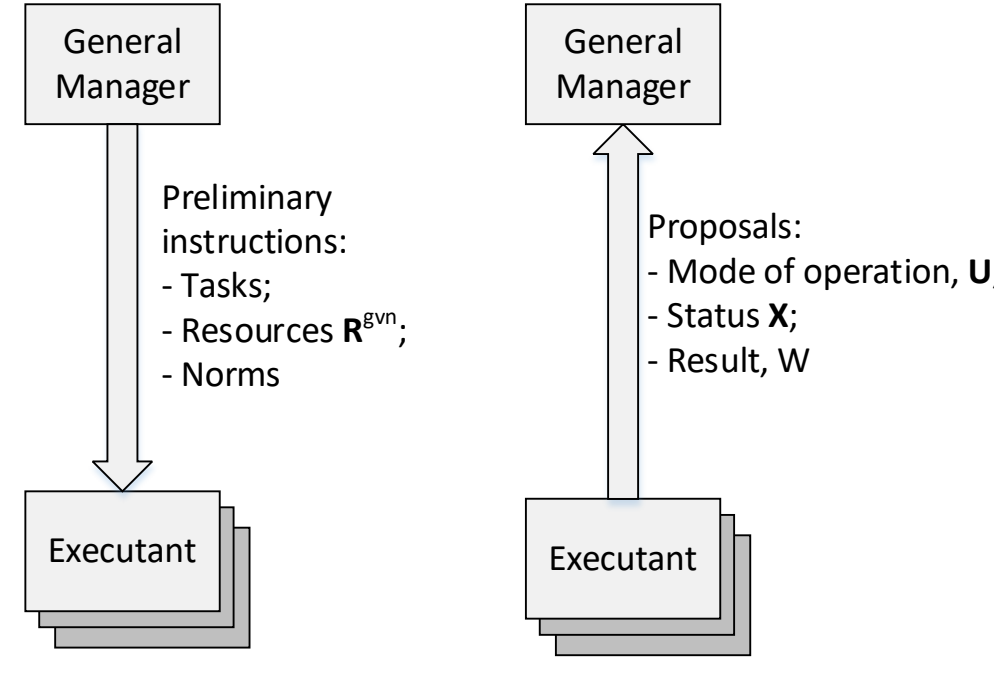

\section{Decision making process}

As disadvantages of the approach [38], it should be noted that the aspects of management or the space of decision making are invariant. The set of information-calculation procedures (fig. 3), the procedure for generating alternative options, the criteria for their assessment - for all cases of decision-making are unchanged. Although, for various aspects of activity, it is often required to significantly transform the decision-making space, change the degree of detail of the mathematical models used, the logical sequence of calculations, the parameters of the criteria for choosing alternatives.
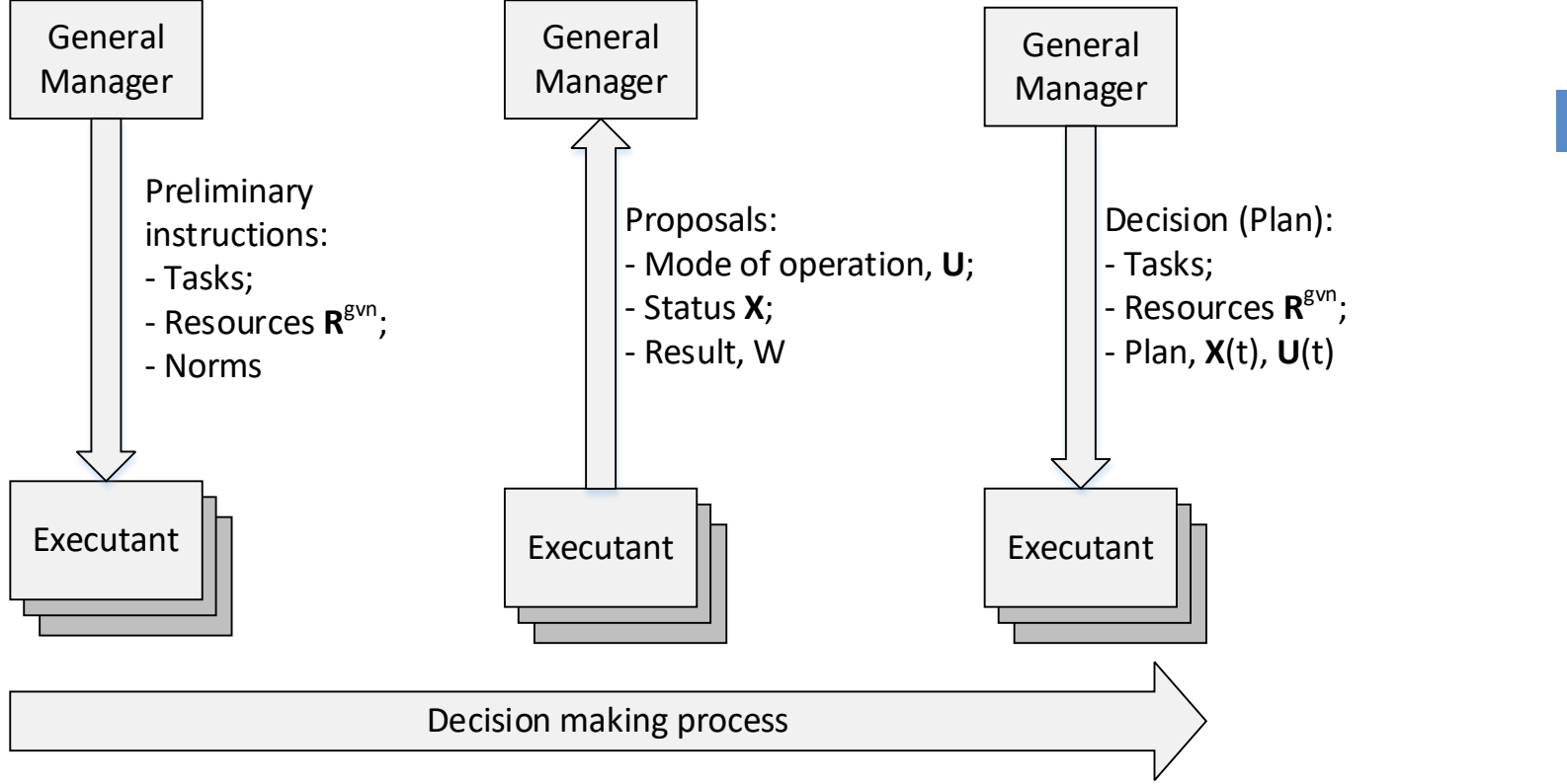

To compensate for these shortcomings developers of ACS [38] was realizes Ana possibility of non-automated formed of procedural regulations decision-making, and also performed maximizing the completeness of the set of calculation procedures for the taken into account aspects of management.

I.e, distributed method of forming alternatives variants (ontology) activity allows to realize managemen for a priori certain situations - situational management. The tasks of ontology adaptation when expanding the list of aspects of management (in the implementation of management according to certain aspects), at this stage, cannot be considered solved and require further research.

\section{Tasks Further Scientific Research}

Based on the results obtained on the design of the ACS of crisis management, the following tasks should be distinguished for further scientific research. This is, firstly, the task of transformation of decisionmaking space in accordance with the changing aspects of management. In a secondly, the task of constructing (change) procedures system, providing a quantitative assessment of alternatives in a given space. In a thirdly, the task of synthesizing alternative solutions from elements of the ontology of activity.

A clearly defined decision-making space allows formalizing, and therefore automating, such elements of crisis management as:

- classification of hypothetical states for the implemented management maneuver, or, in other words, the generation of variants of alternativesfor decision-making. For example, if three parameters, $P_{1}, P_{2}$ and $P_{3}$ (fig.6) are selected as metrics of the decision-making space, then 27 states of the control object can be considered (classified) as hypothetical management situations, if we take a three-level scale of changes in the parameters $P_{i}, i$ $=1,2,3$;

- quantitative assessment of alternatives when making a decision. Based on the entered state parameters, objective functions and management criteria can be formulated. For example, as a measure of the vector difference 


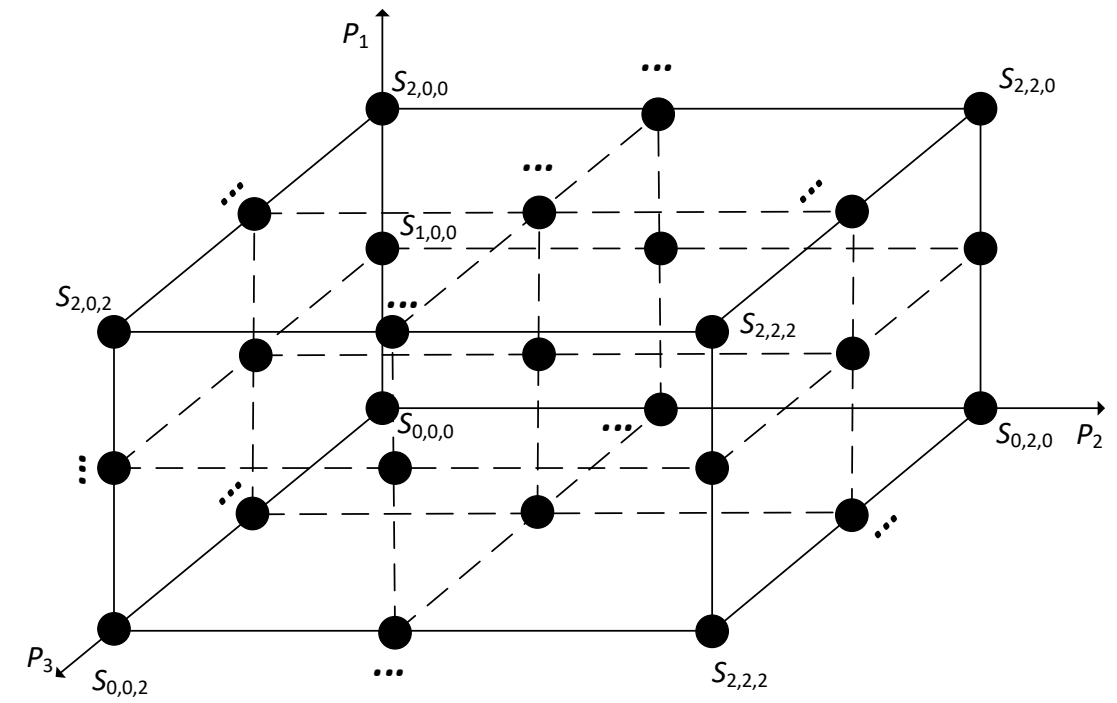

Figure 6: Decision space and classification of hypothetical states

$$
\Delta=\sum_{i=1}^{M}\left(x_{i}-x_{i}^{*}\right)^{2},
$$

where $x_{i}, x_{i}^{*}$ - is the realized (actual) and specified value of the $i$ - th state parameter;

$M$ - the dimension of the decision-making space.

The difficulty, in relation to the construction of the decision-making space, is to obtain the extremely generalized characteristics of the description of hypothetical management situations. These characteristics should be invariant to changes in management aspects, and should also allow their deployment (detailing), taking into account the features (aspects) of the implemented management maneuver.

Obtaining the most generalized characteristics for the considered control processes is a non-trivial task that requires, for its effective solution, a lot of practical experience in a specific area of activity. So, in the field of military strategy, A.A. Svechin [39] singled out as such generalized parameters: space; time; strength (military strength). For socio-economic systems, P.G. Kuznetsov in [40], as the maximum generalized characteristics, considered: power of production, energy production power; the efficiency of using the manufactured product; the rate of change of socially necessary time. As can be seen from the above examples, the extremely generalized parameters are closely related to such concepts as: "power", "work performed", "speed of work", "energy".

It was also noted in [40] that the invariant with respect to different coordinate systems (a change in control aspects can be considered as a change in the used coordinate systems (control spaces)) is power. The table measures Kuznetsova - Bartini shown there, the power is represented as a ratio metrics length and time, raised to the fifth degree $L^{5} / T^{5}$, the power change as the ratio of the length to the fifth power to the time of the sixth degree, $L^{5} / T^{6}$, the power transmission rate is the ratio of length and time to the sixth power, $L^{6} / T^{6}$. The power indices, interpreted in terms of space-time characteristics, for the mentioned table of measures, have the highest exponents of the degree to which these characteristics are raised. This circumstance indicates that the indicators, which are based on the power factor, are an invariant under multi-aspect control, they represent an extremely generalized description of the decision-making space. Therefore, studies on the construction of the decision-making spaces should be in line with the interpretation of the concepts of "power", "change of power", "power transfer rate" in relation to automated de uem second activity. This will make it possible to form an initial space that is invariant to the considered aspects of control. Further, it is necessary to solve the problem of concretization or detailing of generalized (invariant) indicators for management according to the established aspect. When concretization generalized parameters, it is advisable to use the method of categorical analysis, an example of using which in relation to the formation of a space of control for a group of unmanned aerial vehicles is described in [41].

The construction (reconfiguration) of a system of computational procedures for a variable decisionmaking space is the second task of advanced research, which is closely related to the first. In a generalized form, the problem of synthesizing procedural regulations for a given decision-making space can be formulated as follows.

Let there be some decision-making space, which is defined using the generalized parameters $P_{1}$, $P_{2}$ and $P_{3}$. Pooled parameters detailed in accordance with the considered management aspect on groups parameters $p_{i}, i=1, \ldots, N$, and they are - in a group of parameters $q_{j}, j=1, \ldots, Q$, where $N$ and $Q$ - amount 
parameters of the second and first hierarchical levels of detail, respectively (fig. 7).

On the established parametric groups, a library of mathematical models (algorithms, procedures) is defined, which allow expressing some parameters in terms of others (fig. 7)

$$
\mathfrak{M}_{m}\left(\boldsymbol{X}_{m}^{\mathrm{in}}, \boldsymbol{X}_{m}^{\mathrm{rz}}, \boldsymbol{T}_{m}\right)=0, \quad m=1, \ldots, M^{\mathrm{mdl}}
$$

where $\boldsymbol{X}_{m}^{\text {in }}$ - a list of parameters that form a subset of their general structure, which are input data for the $m$-th mathematical model;

$\boldsymbol{X}_{m}^{\mathrm{rz}}$ - a list of parameters that are output data for the model under consideration (the results of the procedure);

$\boldsymbol{T}_{m}$ - vector of time moments characterizing the input and output of the $m$-th mathematical model;

$M^{\mathrm{mdl}}$ - the number of mathematical models in the library.

Subsets of parameters used in different mathematical models may overlap

$$
\begin{gathered}
X_{m} \cap X_{k} \neq \emptyset, \\
X_{m}=\left(X_{m}^{\mathrm{in}}, X_{m}^{\mathrm{rz}}\right), X_{k}=\left(X_{k}^{\mathrm{in}}, X_{k}^{\mathrm{rz}}\right), \\
m \neq k=1, \ldots, M^{\mathrm{mdl}} .
\end{gathered}
$$

That is, the library of mathematical models is redundant in relation to the considered decision-making space.
The task of synthesis of procedural regulation can be written as the problem of finding the list and the order of activation of mathematical models according to the criterion of minimizing the "path" (the number of computational procedures used) and when the condition for determining with a given accuracy the values of parameters from the established list

$$
\begin{gathered}
L\left(\ldots, \mathfrak{M}_{m}\left(X_{m}^{\mathrm{in}}, X_{m}^{\mathrm{rz}}, T_{m}\right), \ldots\right)=\min , \\
L \leq M^{\mathrm{mdl}}, X_{m}^{\mathrm{in}} \in Y, X_{m}^{\mathrm{in}} \in X_{k}^{\mathrm{rz}}, k=1, \ldots,(m-1), \\
X^{*} \in\left(X_{1}^{\mathrm{rz}} \cup \ldots \cup X_{m}^{\mathrm{rz}} \cup \ldots \cup X_{L}^{\mathrm{rz}}\right),
\end{gathered}
$$

where $L^{-}$is an ordered list of mathematical models (calculation procedures) selected in the generated calculation rules. The order of the procedures in the $L$ list is consistent with the order of their activation;

$Y$ - a list of parameters of the "exit" from the controlled object (initial data entering the control system);

$X^{*}$ - a list of state variables which must be defined for management, according to the aspects taken into account.

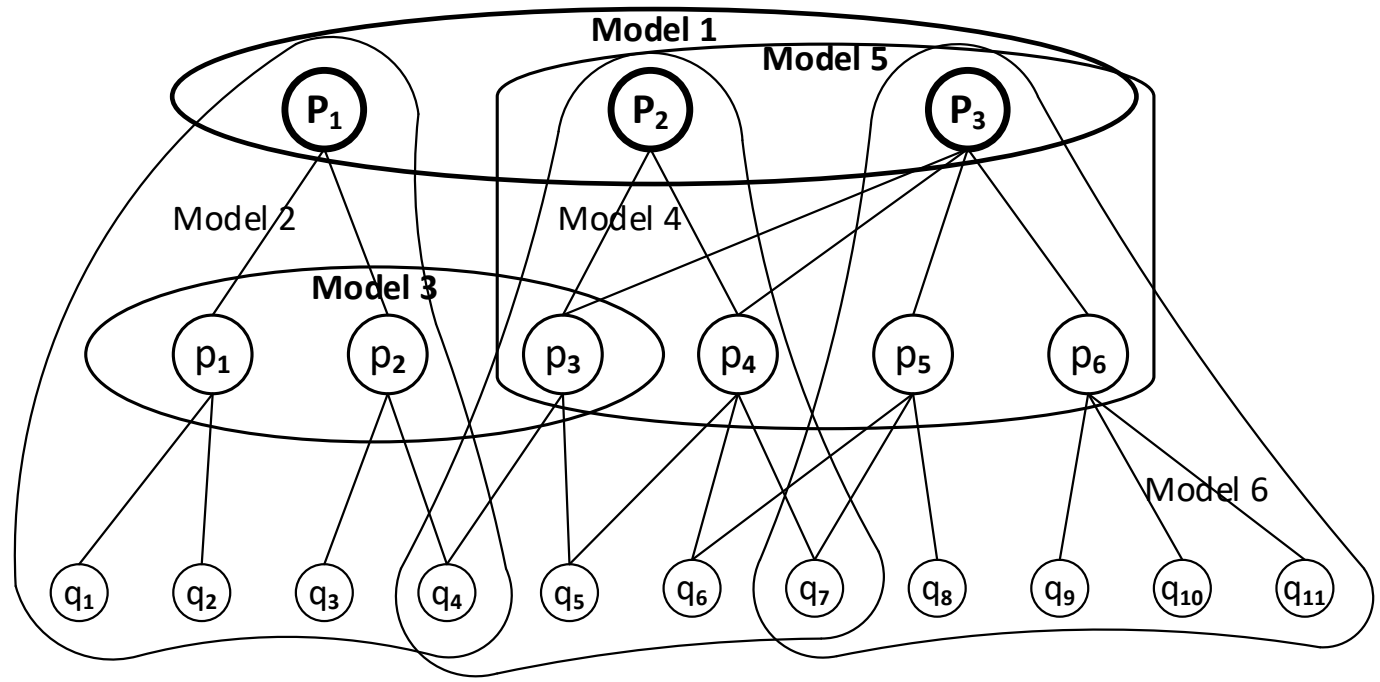

Figure 7: The initial structure of mathematical models and of parameters of the decision-making space

Task (8) - (9) belongs to the type of assignment problems. To solve it, well-known algorithms can be apply to solve problems of this type. Can also be used the methods tensor transform of networks [30].

To reduce task (8)-(10) to the problem of tensor transformation of a network, the initial structures of the models and parameters of the decision-making space (fig.7) should be interpreted in the form of an electrical network (fig.8). Mathematical models are represented here in the form of electrical circuits consisting of nodes (input and output parameters) and inductances (laboriousness of procedures for determining unknown values). Links between nodes can be removed. When some connections are removed between nodes, electrical circuits in the network are opened (fig.8). The corresponding mathematical model (procedure) is excluded from consideration. The presence or absence of a bond between pairs of nodes is specified using the bond tensor. It is necessary to find a tensor of network connections, at which the specified network properties 
could be achieved. When voltage is applied to the nodes, a voltage must be set in them, which interprets the initial data - data that enter the control loop.

The task of synthesizing alternative solutions from elements of the ontology of activity, the third problem of prospective research, can also be considered as an assignment task. The problem of the large dimensionality of the task leads to the need to use special techniques and restrictions for the implementation of synthesis algorithms, which should work in an acceptable time frame. In [38], the synthesis was carried out mainly by the expert method, when the options for the actions of the subordinate centers were prepared in a distributed way. The prepared options were ranked according to the particular criteria established by the decision maker, taking into account the restrictions also introduced by the decision maker.
The synthesis of solutions was from the selected variant of alternatives.

When using the formulation of problem (8) (10), it is possible to construct a formalized procedure for the synthesis of a solution, provided that there are already formed options for the actions of subordinate centers.

In the absence formed option $s$ action subordinate centers, it is necessary to solve the problem of their synthesis based on the ontology elements (elements of activity of the first level: the elements selected technologies, the steps specific tasks, modes complexes (means), and so on). Using the approach of tensor transformations of networks, such elements of the ontology of activity can be represented in the form of a degenerate or primitive, according to Kron [30], an electrical network (Fig.9).

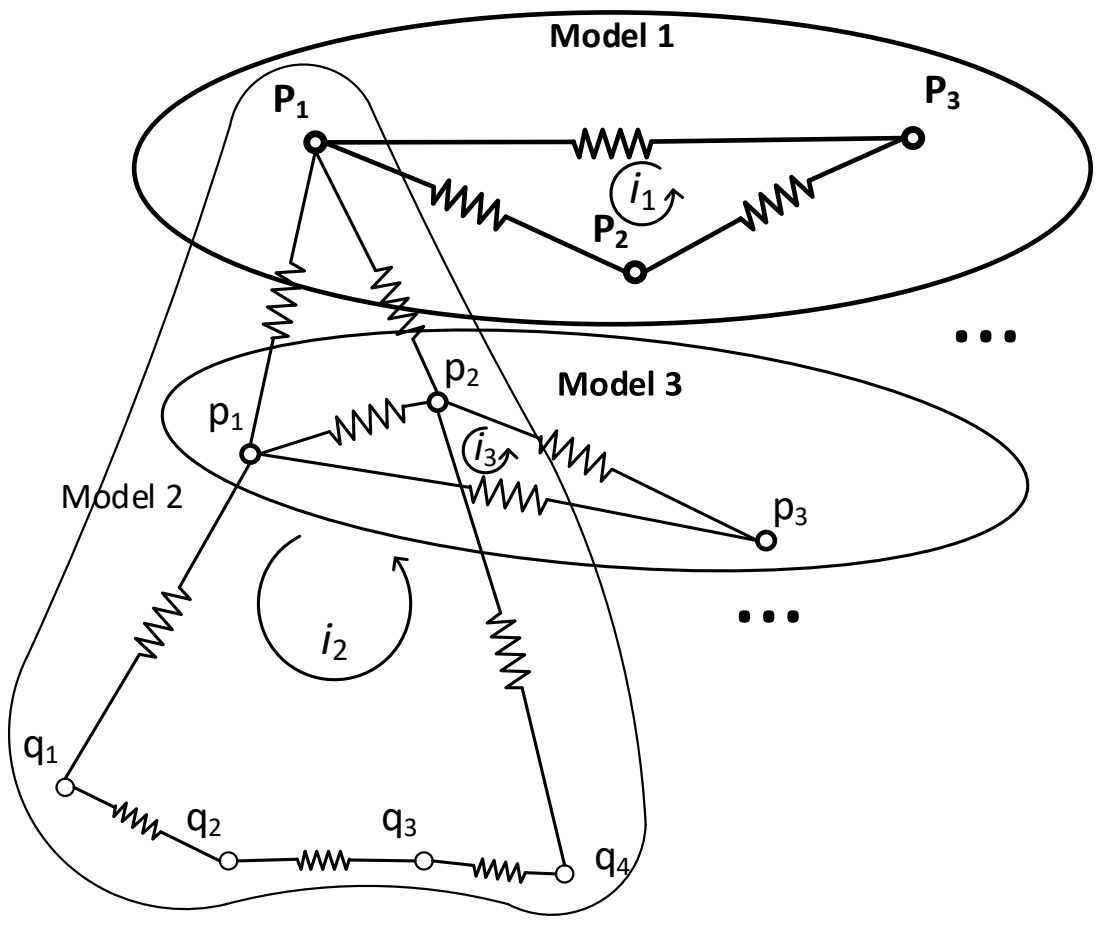

Figure 8: The structure of mathematical models and of parameters presented in the form of an electrical network

Each element is interpreted as a set of two nodes, $\left(C_{i} ; C_{j}\right)$, connected by a conductor with inductance and corresponding impedance, $z_{i, j}$. Nodes are actions (states), detailed down to the first (lower) hierarchical level of activity. For example, node $C_{i}$ can be interpreted as the beginning of the takeoff of the aircraft . The node $C_{j}$ - as the end of the climb to the set height. Then the element ( the $C_{i}$; the $C_{j}$ ) - there is a process of climb. The impedance, $z_{i, j}$, characterizes the complexity of the operation to make the transition from the first to the second state. The impedance of the element under consideration generally depends on the direction of the current. There are cases when the current flow is possible only in one direction. The impedance for the forbidden direction of the current takes on an infinite value. An instantaneous voltage is applied to one of the nodes. Depending on the magnitude of the electric voltage applied to the first node, as well as on the magnitude of the impedance, an instant electric current of a certain strength, $i_{\mathrm{i}, \mathrm{j}}$, arises in the conductor. A certain instantaneous tension arises at the second node. 

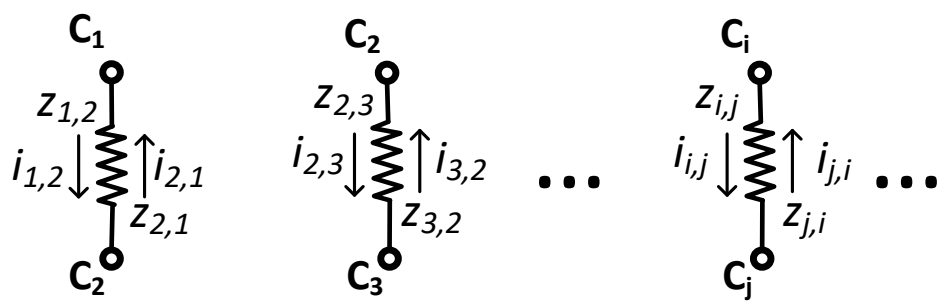

Figure 9: Degenerate (primitive) electrical network of ontology elements

The task of synthesizing the options for the actions of subordinate centers is presented as the task of finding the tensor of connections (transformation) of a primitive electrical network into a network with given properties. These properties include:

- Values of instantaneous stresses at installed nodes;

- Sequence of voltage supply to the nodes.

The set of nodes to which voltage should be applied, and the order in which voltage is applied to these nodes, are determined on the basis of a formalized description of the goals and objectives of the organization. Such a formalized description is possible if there is a formalized representation of the decisionmaking space.

\section{Conclusion}

In this ways, the crisis management has a number of problems associated with poor structuring and multifaceted tasks of management. One of the possible methods for solving these problems is the automation of management processes. This causes relevant solutions tasks for the development scientificmethodological apparatus for designing poliaspektnyh ACS.

The development of mathematical models and methods that provide a formalized description of decision-making processes under conditions of initial uncertainty (multidimensionality) of management occurs in three directions: increasing the degree of detail to practically significant levels; consideration of the factor of subjectivity of the lower-level decision-making centers; development of properties of rapid adaptation of management to changing management aspects.

The implementation of crisis management based on the ontological network of the organization's activities provides a number of advantages in terms of enhancing the detail and adaptability of the formed management decisions. In this case, the process of forming a solution looks like a threefold grouping of ontology elements and discrete moments time.

At the present time, for the design of corporate ACS, the method of distributed formation of an ontological network with the grouping of its elements based on expert methods using the ordering of alternatives according to partial criteriahas been realized. This approach is consistent with the decision- making mechanism widespread in practice with a counter-method of collecting initial data. This approach allows one to take into account such factors as the hierarchy of the control system and the subjectivity of the subordinate decision-making centers.

For further development of scientific and methodological apparatus of crisis control the actual are the following tasks:

- Formation of decision-making spaces, defined on sets of extremely generalized characteristics, invariant to various aspects of control. Obtaining extremely generalized characteristics can be carried out by interpreting the concepts of "power", "change in power", "power transmission rate" in relation to the activity under consideration;

- Concretization of extremely generalized parameters for the actual aspect of management. The solution to this problem is possible on the basis of the categorical analysis method;

- Construction (reconfiguration) of the system of computational procedures for the formed decisionmaking space. This task is classified as an assignment task. It can be solved if there is a redundant library of algorithms and programs. One of the possible ways to solve this problem is the tensor network transformation method;

- Synthesis of alternative solutions from elements of ontology. The task is also a type of assignment problem with a large data dimension. A promising direction that allows us to overcome the difficulty of large dimensions is the reduction of the synthesis problem to the problem of tensor transformation of a primitive electrical network to a network with specified properties (the values of instantaneous voltages and the sequence of their supply to the nodes of the transformed network).

\section{References Références Referencias}

1. Энергетика в России (1920 - 2020 г.г.). Том 1. План ГОЭЛРО. - М.: ИД Энергия. - 2006. - 1067 с.

2. Леонтьев В.В. Межотраслевая экономика/ В.В. Леонтьев - М.: Экономика. - 1997

3. Канторович Л.В. Математические методы организации и планирования производства/ Л.В. Канторович - Л.: Изд-во ЛГУ. - 1939. - 68 с. 
4. Немчинов В.С. Экономико-математические методы и модели/В.С. Немчинов - М., Мысль, 1965. -253 c.

5. Интриллигатор M. Математические методы оптимизации и экономическая теория/Пер. с англ. М., Прогресс, 1975. - 321 с.

6. Акофф Р. Планирование в больших экономических системах. - М., Советское радио, 1970. - 324 с.

7. Оптнер С. Системный анализ для решения деловых и промышленных проблем/С. Оптнер. - М.: Советское радио. $-1969 .-70 \mathrm{c}$.

8. Хитч Ч. Руководство обороной/Ч. Хитч. - М.: изд. «Советское радио». - 1968

9. Янг С. Системное управление организацией Пер. с англ. под ред. С.П. Никанорова, С.А. Батасова/ С. Янг. - М.: «Советское радио». - 1972. - 456 с.

10. Кондратьев Н.Д. Спорные вопросы мирового хозяйства и кризиса (Ответ нашим критикам)/ Н.Д. Кондратьев//Мировая экономика и международные отношения №9. - 1988 [1923]. С. 64 - 76.

11. Кондратьев Н.Д. Проблемы экономической динамики и статики/Н.Д. Кондратьев - М.: Экономика, 1989 [1931] - 526 с.

12. Landauer $\mathrm{C}$. Theory of national economic planning. University of California Press, Berkeley, California. 1944

13. Зельднер А.Г. Партнёрские отношения государства, бизнеса и общества в условиях смешанной экономики/А.Г. Зельднер. - М., ООО «Экономические науки». - 2010

14. Бурков В.Н. Механизмы функционирования организационных систем/В.Н. Бурков, В.В. Кондратьев. - М.: Наука, Главная редакция физикоматематической литературы. - 1981. - 384 с.

15. Гермейер Ю.Б. Игры с непротивоположными интересами/Ю.Б. Гермейер//Оптимизация и исследование операций. Под ред. Н.Н. Моисеева М., Наука Главная ред. физ.-мат. литературы. 1976. - 328 c.

16. Nash J.F. Non-cooperative games. Ann. Math. 54

17. John von Neuman and Oskar Morgenstern Theory of games and economic behavior. Princeton University Press, Princeton. - 1953.

18. Никифоров А. В. Теоретические основы автоматизации управления в иерархических АСУ войсками/A. В. Никифоров//Международный журнал «Sciences of Europe». - Praha, Czech Republic, 2016. - Вип. 9 (9). Militaryscience. С. $32-44$.

19. Моисеев Н.Н. Информационная теория иерархических систем/Н.Н. Моисеев//Труды Всесоюзной конференции по исследованию операций. - Минск. - 1974. - С. 95 - 99.

20. Моисеев Н.Н. Математические задачи системного анализа. - М., Наука, 1984. - 482 с.

21. Хачиян Л.Г., Эрлих А.И. Серийные игровые процессы решения задач выпуклого
программирования/Техническая кибернетика, 1978. - №2, - C. $193-196$.

22. Beni G. Swarm Intelligence in Cellular Robotic Systems, Proceed. NATO Advanced Workshop on Robots and Biological Systems/G. Beni, J. Wang, Tuscany, Italy, 1989. P. 26-30

23. Lewis F.L. Cooperative Control of Multi-Agent Systems: Optimal and Adaptive Design Approaches (Communications and Control Engineering)// F.L. Lewis, H. Zhang, K. Hengster-Movric, A. Das. Springer, 2014. $-307 \mathrm{p}$.

24. Виттих В.А. Мультиагентные модели взаимодействия для построения сетей потребностей и возможностей в открытых системах/ В.А. Виттих, П.О. Скобелев//Автоматика и телемеханика. Выпуск 1. - 2003. - С. $177-185$

25. Смирнов С.В. Онтологии как смысловые модели / С.В. Смирнов//«Онтология проектирования» - 2013. №2. - C. $12-19$

26. Базаров В.А. О методологии построения перспективных планов / В.А. Базаров // Плановое хозяйство. №2. - 1928

27. Carl Builder referred to the 2025 Alternate Futures study as "the finest research project ever to come out of Air University." Meeting of the 2025 Strategic Air Warfare Study International, Maxwell AFB, AL, January 1996

28. Dewar J.A. The importance of wild cards scenarios //www.cia.gov/nic

29. Гвардейцев М.И. Математическое обеспечение управления. Меры развития общества/ М.И. Гвардейцев, П. Г. Кузнецов, В.Я. Розенберг. - М.: «Радио и связь». - 1996. $-176 \mathrm{c}$.

30. Kron G. Tensor analysis of networks. John Wiley and sons, inc. London: Capman and Hall, Limited. New York. - 1966. - 720 p.

31. Кононенко А.А. Технология концептуального проектирования / А.А. Кононенко, З.А. Кучкаров, С.П. Никаноров, Н.К. Никитина//ISBN 978-588981-079-7. - М.: Концепт. - 2008. - 580 с.

32. Иванов А.Ю. Справочник по теоретикосистемным конструктам. Серия «Концептуальный анализ и проектирование». Методология и технология/А.Ю. Иванов, С.П. Никаноров, Ю.Р. Гараева//ISBN 978 5-88981-087-2. - М.: Концепт. - 2008. - 314 c.

33. Бурбаки Н. Теория множеств. Структуры. - М.: Мир. -1965

34. Никаноров С.П. Введение в концептуальное проектирование АСУ: анализ и синтез структур / С.П. Никаноров, Н.К. Никитина, А.Г. Теслинов // Репринтное издание. - М.: Концепт. - 2007. $236 \mathrm{c}$.

35. Никаноров С.П. Исследования по безопасности / С.В. Выборнов, А.Ю. Иванов, С.Е. Корипаков, А.В. Костюк, В.А. Кучкаров, В.В. Михеев, 
С.П. Никаноров, С.К. Шаляпина // Под общ. ред.

С.П. Никанорова. - М.: Концепт. - 2006. - 624 с.

36. Бир С.Кибернетика и менеджмент. Перевод с английского / С. Бир - М.: УРСС. - 2006. -280 с.

37. Ботвинник М.M. О решении неточных переборных задач / М.М. Ботвинник, Б.М. Штильман, М.А. Цфасман, А.Д. Юдин, А.И. Резницкий - М.: Сов. радио, 1979. - 152 с.

38. Nikiforov A. Modeling Complexes of Organizational Management Automated Systems - a Means to Overcome the Management Crisis / Dodonov A., Nikiforov A., Putyatin V., Dodonov V. // Selected Papers of the XIX International Scientific and Practical Conference "Information Technologies and Security" (ITS 2019) Kyiv, Ukraine, November 28, 2019. ISSN 1613-0073 - Vol-2577 urn:nbn:de:00742577-8, p. $100-115$

39. Свечин А. А. Стратегия. - М.-Л.: Госвоениздат, 1926. - $400 \mathrm{C}$.

40. Гвардейцев М.И. Математическое обеспечение управления. Меры развития общества / М.И. Гвардейцев,П.Г. Кузнецов, В.Я. Розенберг. - М.: «Радио и связь». - 1996. - 176 с.

41. Nikiforov A. Applying the method of categorical analysis for conceptual design of an automated control system of a group of unmanned aerial vehicles/Nikiforov A., Klushnikovl.//ISAIC 2020. IOP Publishing. Journal of Physics: Conference Series. Ser. 1828 (2021) 012069. doi: 10.1088/17426596/1828/1/012069, $17 \mathrm{p}$. 